\begin{tabular}{|c|c|}
\hline PORT SAID ENGINEERING RESEARCH JOURNAL \\
Faculty of Engineering - Port Said University \\
Volume (21) No. (2) September 2017 pp. 181:192
\end{tabular}

\title{
ENERGY AND EXERGY ANALYSIS OF A STEAM POWER PLANT AT PART LOAD CONDITIONS
}

\author{
Idris A. Elfeituri ${ }^{1}$ and A. Abd Almotalip ${ }^{2}$
}

\begin{abstract}
A steam power plant can run at off-design due to change of ambient conditions or load demand. This needs to study how part-load affects the power plant performance. In this paper, the results of energy and exergy analysis carried out on a 65 MW Derna steam power plant in Libya at part load conditions are presented. The article aims to identify the magnitude, location and source of thermodynamic inefficiencies in the steam power plant at part loads. The performance of the plant was estimated by a component-wise modeling and a detailed break-up of energy and exergy losses for the considered power plant. The required outputs (power, heat and exergy destruction) of the various components and for the whole plant were assessed and calculated using mass, energy and exergy balance equations of the developed model. Based on this model, a computer program was written and used to investigate the performance of the power plant. According to the results, for full and part loads, the largest amount of energy loss occurs in the condenser and the least occurs in the boiler. In terms of exergy, the major exergy destruction was found to be maximum in the boiler, followed by the turbine, and then the condenser. The results revealed remarkable dependency of overall energy and exergy efficiencies, total exergy destruction ratio, heat rate and specific fuel consumption on the change in the load of the power plant. In conclusion, the results show how energy and exergy have been used to locate places of inefficiencies in the power plant operating at different loads.
\end{abstract}

Keywords: Energy, Exergy analysis, Modeling, part-load, Efficiency, Steam power plant.

\footnotetext{
${ }^{1}$ Department of Mechanical Eng., University of Benghazi (phone: +218-94-471-0641; e-mail: idrisffff@ yahoo.com).

2 Department of Mechanical Power Engineering, Faculty of Engineering, University of Port Said; Alabady-848 @ yahoo.com
} 


\section{INTRODUCTION}

A steam power plant is a complex assembly of various components and the design operation theories of these components are complex. They often run at off-design conditions due to change of load. Therefore, when evaluating the overall performance of the power plant, it is important to account for all operating conditions that can be encountered. Furthermore, the merit of the steam power plant system should be determined using exergy analysis because energy analysis tends to overestimate performance [1]. It is known that the most effective way to use energy more efficiently is through the energy and exergy analysis [2]. Exergy can be defined as the maximum useful work that can be obtained from the system $[1,2]$. The exergy analysis method is based on second law of thermodynamics. Therefore, it is used to see the various losses qualitatively as well as quantitatively for the design and analysis of energy systems. On the other hand, energy analysis is based on the first law analysis, which does not give the qualitative assessment of various losses occurring in the individual component of the power plant [3]. Therefore, exergy analysis can be used to determine the location, type and true magnitude of exergy destruction or loss in system performance.

The use of energy and exergy analysis in thermal power plants has been discussed and performed by many researchers. Dincer and Al-Muslim [4] analyzed a Rankine cycle reheat steam power plant to study the energy and exergy efficiencies at different operating conditions with varying boiler temperature, boiler pressure, mass fraction ratio and work output from the cycle. Regulagadda et. al. [5] used the exergy analysis for a thermal power plant with measured boiler and turbine losses. Rana and Mehta [6] presented the energy and exergy analysis of fully condensing steam turbine at various steam load conditions.
Exergy analysis of using design data of an actual power plant was done by; Fallah [7] in Libya, Aljundi [8] in Jordan, Regulagadda et al. [9] in India, Ousueke et. al. in Nigeria [10] and Rashad and El-Maihy in Egypt [11]. They presented a parametric study to determine how the system performance varies with different operating parameters using commercial software. They analyzed the system components separately, identified and quantified the sites having largest energy and exergy losses at different operating conditions. They found that the highest exergy losses take place in the boiler, while the highest energy losses occur in the condenser. They also showed that the overall energy and exergy efficiencies of the power plant decrease with the decrease in power plant load or an increase in ambient temperature.

However, in the published literatures, the effect of part-load operation on the performance of steam power plant using exergy concept has not been studied widely. If so, most of the analysis presented in these literatures was done with the mass and energy balance commercial software. Therefore, the primary objective of this work is to develop and demonstrate a mathematical model which takes into account the off-design operation of the whole plant and its components. The secondary objective is to perform energyexergy analysis on an actual steam power plant at different loads. In addition to these studies, sites of energy loss and exergy destruction will be determined.

\section{POWER PLANT DESCRIPTION}

The schematic diagram of the thermal power plant is presented in Fig. 1. This plant is installed in the Derna power station located in Derna city (north west-Libya). The power plant has a total rated capacity of $65 \mathrm{MW}$. It was designed and built in 1980 by BBC [12]. 


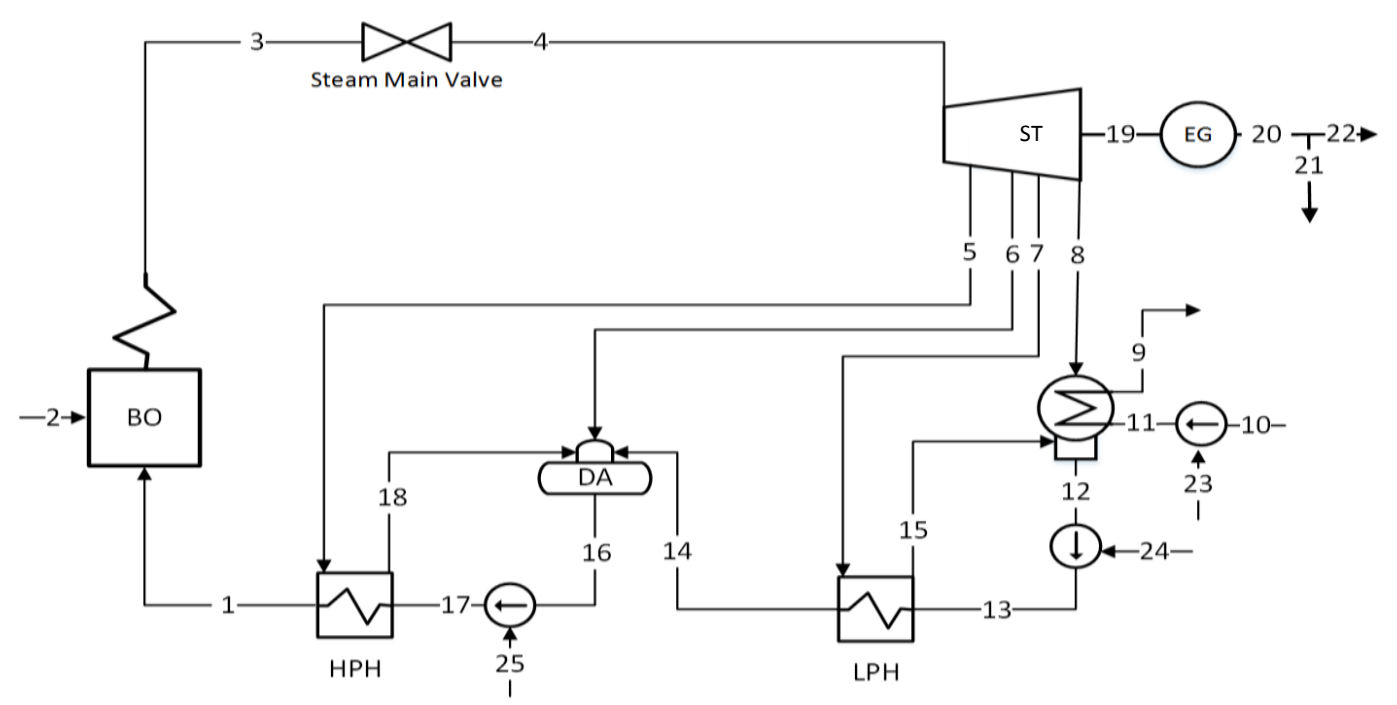

Figure 1: Schematic diagram of Derna steam power plant cycle.

The only, plant components that strongly effect the operation of the system under the study are considered. Thus, the real plant structure is simplified by omitting some of its insignificant flows and components such as steam seals and ejectors, flue gases drought system, air heater and stand by flows and components. This unit employs regenerative feedwater heating system with three stages of extraction points. Feedwater heating is carried out in one stage of low pressure heater (LPH) and one stage of high pressure heater $(\mathrm{HPH})$ along with one open de-aerating heat exchanger (DA). The steam pressure at boiler exit, point 3 , is 88.5 bar and superheated to $520{ }^{\circ} \mathrm{C}$. The steam is fed to the turbine (point 4) at pressure of 87 bar. The turbine exit steam at point ' 8 ' is sent to the main steam-condenser $(\mathrm{CON})$ and condensed at 0.062 bar. Then, the cycle starts over again. Table 1 presents the design data and assumptions used to calculate thermodynamics properties and values at various points in the cycle at full load condition.

Table 1: Design data of the power plant at full-load condition [12].

\begin{tabular}{|c|l|l|}
\hline Point & \multicolumn{1}{|c|}{ Parameters } & \multicolumn{1}{|c|}{ Remarks } \\
\hline 1 & $\mathrm{p}=92.0$ bar, $\mathrm{T}=214.0^{\circ} \mathrm{C}$ & Water \\
\hline 2 & $\mathrm{~L} H \mathrm{~V}=43 . \mathrm{MJ} / \mathrm{kg}, \mathrm{m}_{\mathrm{f}}=4.5 \mathrm{~kg} / \mathrm{s}, \eta_{\mathrm{BO}}=88 \%$ & heat supply by fuel in the boiler \\
\hline 3 & $\mathrm{p}=88.5$ bar, $\mathrm{T}=520^{\circ} \mathrm{C}$ & superheated steam \\
\hline 4 & $\mathrm{p}=87$ & steam throttling from point 3 \\
\hline 5 & $\mathrm{p}=21.81$ bar, $\eta=83 \%$ & steam expansion from point 4 \\
\hline 6 & $\mathrm{p}=6.023$ bar, $\eta=89 \%$ & steam expansion from point 5 \\
\hline 7 & $\mathrm{p}=1.15$ bar, $\eta=88 \%$ & steam expansion from point 6 \\
\hline 8 & $\mathrm{p}=0.062$ bar, $\eta=71 \%$ & steam expansion from point 7 \\
\hline 9 & $\mathrm{p}=1.5$ bar, $\mathrm{T}=\mathrm{T}_{1}+15$ & Water \\
\hline 10 & $\mathrm{p}=1.013 \mathrm{bar}, \mathrm{T}=15^{\circ} \mathrm{C}$ & Water \\
\hline 11 & $\mathrm{p}=1.75$ bar, $\rho_{\mathrm{w}}=993 \mathrm{~kg} / \mathrm{m}^{3}, \eta_{\mathrm{p}}=85 \%$ & water compression from point 10 \\
\hline 12 & $\mathrm{P}=0.062$ bar & saturated water \\
\hline 13 & $\mathrm{p}=9.0$ bar, $\rho_{\mathrm{w}}=993 \mathrm{~kg} / \mathrm{m}^{3}, \eta_{\mathrm{p}}=85 \%$ & water compression from point 12 \\
\hline 14 & $\mathrm{P}=7.5$ bar, $\mathrm{T}=99.5^{\circ} \mathrm{C}$ & Water \\
\hline 15 & $\mathrm{P}=1.15$ bar & saturated water \\
\hline 16 & $\mathrm{P}=6.023$ bar & saturated water \\
\hline 17 & $\mathrm{p}=91.2$ bar, $\rho_{\mathrm{w}}=993 \mathrm{~kg} / \mathrm{m}^{3}, \eta_{\mathrm{p}}=85 \%$ & water compression from point 16 \\
\hline 18 & $\mathrm{P}=21.81$ bar & saturated water \\
\hline 19 & & turbine mechanical power output \\
\hline 20 & $\mathrm{Generator}$ efficiency $=98 \%$ & gross electrical power output \\
\hline
\end{tabular}




\begin{tabular}{|l|l|l|}
\hline 21 & & auxiliary power consumed by plant \\
\hline 22 & & net electrical power output \\
\hline 23 & & power to cooling water pump \\
\hline 24 & & Power to condenser extraction pump \\
\hline 25 & & power to boiler feedwater pump \\
\hline
\end{tabular}

\section{ENERGY AND EXERGY ANALYSIS}

In order to perform the energy and exergy analysis the following assumptions are considered:

- All processes are assumed as steady-state and steady flow.

- The kinetic, potential and chemical exergy are neglected.

- The dead state was considered as $\mathrm{p}_{\mathrm{o}}=1.0131$ bar and $\mathrm{T}_{0}=25^{\circ} \mathrm{C}$.

- The inlet cooling water and turbine steam temperatures were kept constant.

- The part-load control method is the control of the fuel supply in the boiler.

- The overall conductance $(U A)$ for heaters and condenser were kept constant.

- Saturate liquid at the shell side of the LPH and HPH outlets.

- The auxiliary power is equals the electrical power consumed by the all water pumps.

For an open system and taking into account the indicated assumptions, the mass, energy and exergy balance equations can be expressed as [1, 2, 14 and 15]:

Mass balance equation:

$\sum \dot{\mathrm{m}}_{\text {in }}-\sum \dot{\mathrm{m}}_{\text {out }}=0.0$

Energy balance equation:

$\sum \dot{\mathrm{m}}_{\text {in }} h_{\text {in }}-\sum \dot{\mathrm{m}}_{\text {out }} h_{\text {out }}+\sum Q_{\text {in }}-$

$\sum Q_{\text {out }}+\sum P_{\text {in }}-\sum P_{\text {out }}=0.0$

exergy balance equation:

$\sum E X_{\text {in }}-\sum E X_{\text {out }}+\sum P_{\text {in }}-\sum P_{\text {out }}-$

$E X D=0.0$

\subsection{Modelling}

With regard of the Fig. 1, each component in the power plant was considered as a control volume and analyzed separately. The mass, energy and exergy balances for each control volume at steady state can be expressed, respectively by:

\subsubsection{Steam Generator Model}

$\dot{\mathrm{m}}_{1}=\dot{\mathrm{m}}_{4}$

$\dot{\mathrm{m}}_{1}=\frac{\left(E N_{2} \times \eta_{B O}\right)}{\left(h_{4}-h_{1}\right)}$

The boiler efficiency is obtained from performance test data of the considered plant [12]. The curve fitting was used to obtain an equation for calculating the boiler efficiency at varying boiler loads. The equation is as:

$$
\begin{aligned}
& \eta_{B O}=\eta_{B O, r} \times\left[0.26+2.5 \times\left(\frac{E N_{2}}{E N_{2, r}}\right)^{2}+\right. \\
& \left.0.7 \times\left(\frac{E N_{2}}{E N_{2, r}}\right)^{3}\right]
\end{aligned}
$$

The reference condition with index $(r)$ is considered as the design condition in this study, and $E N_{2}$ is the energy supplied by fuel in the boiler

$$
\begin{aligned}
& E N_{2}=\dot{\mathrm{m}}_{\text {fuel }} \cdot L H V \\
& E X D_{B O}=E X_{1}+E X_{2}-E X_{4}
\end{aligned}
$$

\subsubsection{Steam Turbine Model}

$\dot{\mathrm{m}}_{4}=\dot{\mathrm{m}}_{5}+\dot{\mathrm{m}}_{6}+\dot{\mathrm{m}}_{7}+\dot{\mathrm{m}}_{8}$

$P_{19}=\dot{\mathrm{m}}_{4} h_{4}-\dot{\mathrm{m}}_{5} h_{5}-\dot{\mathrm{m}}_{6} h_{6}-\dot{\mathrm{m}}_{7} h_{7}-$ $\dot{\mathrm{m}}_{8} h_{8}$

$E X D_{S T}=E X_{4}-E X_{5}-E X_{6}-E X_{7}-$ $E X_{8}-P_{19}$

The pressure at an inlet to the turbine stagegroup is calculated using the relation by [13]

$p_{\text {in }}=\sqrt{\left(\frac{\dot{\mathrm{m}}}{\dot{\mathrm{m}}_{r}}\right)^{2} \times\left(p_{\text {in }, r}^{2}-p_{\text {out }, r}^{2}\right)+p_{\text {out }}^{2}}$

The expansion efficiency of a turbine stagegroup for a dry region at varying operating conditions $\left(\eta_{d r y}\right)$ is calculated using [13]: 
$\eta_{d r y}=\eta_{\text {dry }, r} \times[1+5 \times a-a \times$
$\left.\left(4 \times\left(\frac{p_{\text {out }, r}}{p_{\text {in }, r}} \times \frac{p_{i}}{p_{o}}\right)+\left(\frac{p_{\text {out }, r}}{p_{\text {in }, r}} \times \frac{p_{i}}{p_{o}}\right)^{-4}\right)\right]$

$a=0.000333 \times \exp ^{9.66\left(\frac{p_{\text {out }, r}}{p_{\text {in }, r}}\right)}$

The expansion efficiency of a turbine stagegroup for a wet region $\left(\eta_{w e t}\right)$ is given by [13]:

$\eta_{w e t}=\eta_{d r y} \times\left(x_{\text {in }}+x_{\text {out }}\right) / 2$

$x_{\text {out }}=\frac{2 \times\left(h_{\text {in }}-h_{f, \text { out }}\right)-\eta_{\text {dry }} x_{\text {in }} \times\left(h_{\text {in }}-h_{\text {out }, \text { is }}\right)}{2 \times\left(h_{f g, \text { out }}-h_{f, \text { out }}\right)+\eta_{d r y} \times\left(h_{i}-h_{\text {out }, \text { is }}\right)}$

Where $h_{f}$ and $h_{f g}$ are the saturated liquid and evaporation enthalpies respectively, and $x_{\text {in }}$ and $x_{\text {out }}$ are the steam dryness fraction at inlet and outlet of turbine-stages.

The outlet enthalpy from a turbine stagegroup at dry region $\left(h_{\text {out }}\right)$

$h_{\text {out }}=h_{\text {in }}-\eta_{\text {dry }} \times\left(h_{\text {in }}-h_{\text {out }, \text { is }}\right)$

and at wet region

$h_{\text {out }}=h_{\text {in }}-\eta_{\text {wet }} \times\left(h_{\text {in }}-h_{\text {out }, \text { is }}\right)$

\subsubsection{Condenser Model}

Steam side:

$$
\dot{\mathrm{m}}_{12}=\dot{\mathrm{m}}_{8}+\dot{\mathrm{m}}_{15}
$$$$
Q_{C O N}=\dot{\mathrm{m}}_{8} h_{8}-\dot{\mathrm{m}}_{12} h_{12}+\dot{\mathrm{m}}_{15} h_{15}
$$

Water side:

$$
\begin{aligned}
& \dot{\mathrm{m}}_{9}=\dot{\mathrm{m}}_{11} \\
& Q_{C O N}=\dot{\mathrm{m}}_{11} \times\left(h_{9}-h_{11}\right) \\
& Q_{C O N}=U A_{C O N} \times \Delta T L_{C O N} \\
& \Delta T L_{C O N}=\frac{\left(T_{8, \text { sat }}-T_{11}\right)-\left(T_{8, s a t}-T_{9}\right)}{\ln \frac{\left(T_{8, s a t}-T_{11}\right)}{\left(T_{8, s a t}-T_{9}\right)}}
\end{aligned}
$$

$$
E X D_{C O N}=E X_{8}+E X_{11}-E X_{12}+E X_{15}
$$

\subsubsection{Low Pressure Heater Model}

Steam side:

$$
\begin{aligned}
& \dot{\mathrm{m}}_{7}=\dot{\mathrm{m}}_{15} \\
& Q_{L P H}=\dot{\mathrm{m}}_{7} \times\left(h_{7}-h_{15}\right)
\end{aligned}
$$

Water side:

$$
\begin{aligned}
& \dot{\mathrm{m}}_{13}=\dot{\mathrm{m}}_{14} \\
& Q_{L P H}=\dot{\mathrm{m}}_{13} \times\left(h_{14}-h_{13}\right) \\
& Q_{L P H}=U A_{L P H} \times \Delta T L_{L P H} \\
& \Delta T L_{L P H}=\frac{\left(T_{7, s a t}-T_{13}\right)-\left(T_{7, s a t}-T_{14}\right)}{\ln \frac{\left(T_{7, s a t}-T_{13}\right)}{\left(T_{7, s a t}-T_{14}\right)}}
\end{aligned}
$$

$$
E X D_{L P H}=E X_{7}+E X_{13}-E X_{14}-E X_{15}
$$

\subsubsection{High Pressure Heater Model}

Steam side:

$\dot{\mathrm{m}}_{5}=\dot{\mathrm{m}}_{18}$

$Q_{H P H}=\dot{\mathrm{m}}_{5} \times\left(h_{5}-h_{18}\right)$

Water side:

$$
\begin{aligned}
& \dot{\mathrm{m}}_{1}=\dot{\mathrm{m}}_{17} \\
& Q_{H P H}=\dot{\mathrm{m}}_{1} \times\left(h_{1}-h_{17}\right) \\
& Q_{H P H}=U A_{H P H} \times \Delta T L_{H P H} \\
& \Delta T L_{H P H}=\frac{\left(T_{5, \text { sat }}-T_{17}\right)-\left(T_{5, \text { sat }}-T_{1}\right)}{\ln \frac{\left(T_{5, \text { sat }}-T_{17}\right)}{\left(T_{5, \text { sat }}-T_{1}\right)}} \\
& E X D_{H P H}=-E X_{1}+E X_{5}+E X_{17}-E X_{18}
\end{aligned}
$$

\subsubsection{De-aerator Model}

$$
\begin{aligned}
& \dot{\mathrm{m}}_{16}=\dot{\mathrm{m}}_{6}+\dot{\mathrm{m}}_{14}+\dot{\mathrm{m}}_{18} \\
& \dot{\mathrm{m}}_{14}=\left(\dot{\mathrm{m}}_{16} h_{16}-\dot{\mathrm{m}}_{18} h_{18}+\dot{\mathrm{m}}_{18} h_{6}-\right. \\
& \left.\dot{\mathrm{m}}_{16} h_{6}\right) /\left(h_{14}-h_{6}\right) \\
& E X D_{D A}=E X_{6}+E X_{14}-E X_{16}+E X_{18}
\end{aligned}
$$




\subsubsection{Cooling Water Pump Model}

$$
\begin{aligned}
& \dot{\mathrm{m}}_{10}=\dot{\mathrm{m}}_{11} \\
& h_{11}=\frac{\left(p_{11}-p_{10}\right) \times 100}{\rho_{w} \times \eta_{p}}+h_{10} \\
& P_{23}=\dot{\mathrm{m}}_{10} \times\left(h_{11}-h_{10}\right) \\
& E X D_{C W P}=E X_{10}+E X_{23}-E X_{11}
\end{aligned}
$$

\subsubsection{Condenser Extraction Pump Model}

$\dot{\mathrm{m}}_{12}=\dot{\mathrm{m}}_{13}$

$h_{13}=\frac{\left(p_{13}-p_{12}\right) \times 100}{\rho_{w} \times \eta_{p}}+h_{12}$

$P_{24}=\dot{\mathrm{m}}_{12} \times\left(h_{13}-h_{12}\right)$

$E X D_{C E P}=E X_{12}-E X_{13}+E X_{24}$

\subsubsection{Boiler Feed-Water Pump Model}

$\dot{\mathrm{m}}_{16}=\dot{\mathrm{m}}_{17}$

$h_{17}=\frac{\left(p_{17}-p_{16}\right) \times 100}{\rho_{w} \times \eta_{p}}+h_{16}$

$P_{25}=\dot{\mathrm{m}}_{16} \times\left(h_{17}-h_{16}\right)$

$E X D_{B F W P}=E X_{16}-E X_{17}+E X_{25}$

\section{Pressure drop in Pipes}

The pressure drop in pipes of the cycle's components is calculated from

$$
p_{\text {out }}=p_{\text {in }}-\Delta p_{r} \times\left(\frac{\dot{m}_{\text {in }}}{\dot{m}_{\text {in, }}}\right)^{2}
$$

\subsubsection{Overall Plant Performance Model}

The gross electrical power output $\left(P_{20}\right)$ produced:

$P_{20}=P_{19} \cdot \eta_{G}$

The net electrical power output $P_{22}$ :

$P_{22}=P_{20}-P_{21}$

Where $P_{21}$ is the auxiliary electrical power required to drive the water pumps in the power plant cycle and is given by:

$$
P_{22}=P_{23}+P_{24}+P_{25}
$$

The overall energy efficiency or first law efficiency of the power plant $\left(\eta_{I}\right)$ :

$\eta_{I}=\left(\frac{P_{22}}{E N_{2}}\right) \times 100 \%$

The heat rate $(H R)$ of the power plant (HR) is computed by:

$H R=\frac{3600}{\eta_{I}}$

The specific fuel consumption $(S F C)$ of the power plant is determined by;

$S F C=\frac{H R}{L H V}$

The value of physical exergy flow rate (for water and steam) at various state points in the cycle can be calculated by the following equation [1]:

$E X_{i}=\dot{\mathrm{m}}_{i} \times\left[\left(\mathrm{h}_{i}-\mathrm{h}_{0}\right)-T_{0} \times\left(s_{i}-s_{0}\right)\right]$

where $h_{i}$ and $s_{i}$ are the enthalpy and entropy of the substance (i) respectively, and $h_{0}$, so and $T_{0}$ are those at standard ambient conditions. With using this equation (62) for determined all points, the values of exergy flow rates are calculated. Also, having of input and output exergy flow rate amount of each power plant components, the exergy destruction rate in each component can be calculated with using relations shown above.

Total exergy destruction rate in the whole power plant is given as:

$E X D_{\text {total }}=\sum E X D_{i}$

The exergy destruction ratio $\left(E X D R_{i}\right)$ for each component can be compared to the fuel exergy input to the cycle, and written as:

$E X D R_{i}=\left(\frac{E X D_{i}}{E X_{\text {fuel }}}\right) \times 100 \%$

The total exergy destruction ratio of the plant is given by:

$E X D R_{\text {total }}=\left(\frac{E X D_{\text {total }}}{E X_{\text {fuel }}}\right) \times 100 \%$ 
The overall exergy (second law efficiency) of the power plant $\left(\eta_{I I}\right)$ is given as:

$\eta_{I I}=\left(\frac{\text { exergy rate output }}{\text { exergy rate input }}=1-\frac{E X D_{\text {total }}}{E X_{\text {fuel }}}\right) \times$ $100 \%$

Where, $E X_{f u e l}$ is the exergy supplied by fuel and is given by [2]:

$$
E X_{\text {fuel }}=1.064 \times \dot{\mathrm{m}}_{\text {fuel }} \times L H V
$$

\section{ANALYSIS PROCEDURE}

For the whole system model, since the calculations need the fluid parameters (such as the condenser pressure and flow rates), which are not known at the beginning of the part-load calculation, a set of initial parameters has to be assumed in order to run the system model until convergence is met eventually. Thus, the following calculation method is considered.

At the beginning mass flow rates are estimated. With this method, calculation starts at an appropriate point of the cycle with estimated values. In our case, the calculation started with the condenser. The cycle is then calculated unit after unit following the direction of mass flow. With this estimate all thermodynamic properties are calculated. By setting up and solving the mass and energy balance equations improved values for the mass flow rates obtained. These steps are repeated until the solution reaches the required accuracy.

A computer program was constructed based on the thermodynamic model discussed in the previous section to predict the steam power plant performance at different loads. The externally input data are design data (Table 1) and boiler-load (ranges from $50 \%$ to $100 \%$ ). With these inputs, the program will enable the operating point of each power plant component inlet and outlet properties to be found. The thermodynamic performance as net power output, energy and exergy efficiencies, heat rate, specific fuel consumption and exergy destruction rate in each component of the plant are then calculated using these properties values. The program contains the following models:

A- MBE: This model enables the solution of the balance equations, that is, evaluation of mass, energy and exergy flows for input thermodynamic properties.

B-MTP: This model allows the evaluation of the thermodynamic properties for given mass flow rates. It includes equations that represent each component process and thermodynamic data for water/steam.

C-MPP: This model allows the evaluation of the thermodynamic performance of the plant. The values obtained in models MBE and MTP are used in MPP. With the assumptions made and starting guess of the solution, the operation that take place in the jth iterative process are:

i- The evaluation of mass flows $(\mathrm{Mj})$ based on MBE model.

ii- The evaluation of the thermodynamic properties (TPj) based on MTP model and $\mathrm{Mj}$.

These operations are repeated for each iteration step till no significant improvement in the solution is noticed. Next, the parameters defined by MPP model are determined. Figure 2 shows detail of the calculation algorithm of the program. 


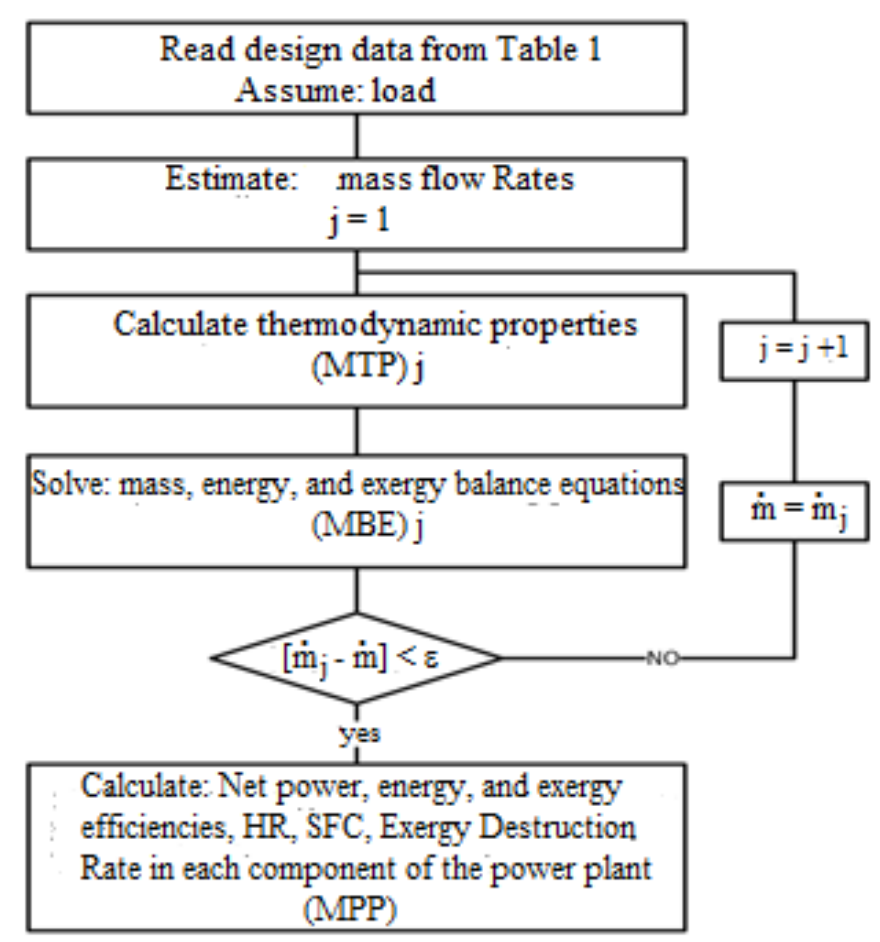

Figure 2: Computer program algorithm.

\section{RESULTS AND DISCUSSION}

In this study, a detailed energy and exergy analysis of the Derna steam power plant is performed at different loads. The thermodynamic properties of water and steam at indicated nodes in Fig. 1 were computed. The mass, energy and exergy flow rates at each component were calculated using these data. The obtained results at full load operation are summarized in Table 2 and shown by Figs. 3 and 4. While the obtained results at different loads are summarized in Table 3 and shown in Figures 5 - 9.

Table 2: Parameters for the analysis at full load.

\begin{tabular}{|c|c|c|c|c|c|c|c|c|}
\hline Points & $\begin{array}{c}\mathrm{p} \\
(\mathrm{bar})\end{array}$ & $\begin{array}{c}\mathrm{T} \\
\left({ }^{\circ} \mathrm{C}\right)\end{array}$ & $\begin{array}{c}\mathrm{h} \\
(\mathrm{kJ} / \mathrm{kg})\end{array}$ & $\begin{array}{c}\mathrm{s} \\
(\mathrm{kJ} / \mathrm{kg} . \mathrm{K})\end{array}$ & $\begin{array}{c}\mathrm{x} \\
(-)\end{array}$ & $\begin{array}{c}\dot{\mathrm{m}} \\
(\mathrm{kg} / \mathrm{s})\end{array}$ & $\begin{array}{c}\text { Energy } \\
(\mathrm{MW})\end{array}$ & $\begin{array}{c}\text { Exergy } \\
(\mathrm{MW})\end{array}$ \\
\hline 1 & 92.00 & 214.2 & 919.3 & 2.450 & 0.0 & 67.48 & 62.04 & 14.48 \\
\hline 2 & $====$ & $====$ & $====$ & $====$ & $===$ & $====$ & 195.36 & 207.87 \\
\hline 3 & 88.50 & 520.0 & 3438.0 & 6.733 & 1.0 & 67.48 & 232.00 & 101.20 \\
\hline 4 & 87.00 & 519.3 & 3438.0 & 6.740 & 1.0 & 67.48 & 232.00 & 101.05 \\
\hline 5 & 21.81 & 334.3 & 3099.2 & 6.857 & 1.0 & 7.40 & 6.81 & 8.33 \\
\hline 6 & 6.023 & 200.6 & 2850.9 & 6.967 & 1.0 & 5.48 & 5.04 & 4.63 \\
\hline 7 & 1.150 & 103.6 & 2610.3 & 7.115 & 1.0 & 6.58 & 6.05 & 3.70 \\
\hline 8 & 0.062 & 36.8 & 2286.0 & 7.408 & 0.88 & 48.02 & 44.14 & 7.35 \\
\hline 9 & 1.500 & 30.0 & 125.8 & 0.436 & 0.0 & 1662.8 & 1528.70 & 2.78 \\
\hline 10 & 1.00 & 15.0 & 63.1 & 0.224 & 0.0 & 1662.8 & 104.82 & 0.00 \\
\hline 11 & 1.75 & 15.1 & 63.2 & 0.224 & 0.0 & 1662.8 & 104.97 & 0.14 \\
\hline 12 & 0.062 & 36.8 & 154.0 & 0.529 & 0.0 & 54.60 & 8.41 & 0.17 \\
\hline 13 & 9.000 & 36.9 & 155.1 & 0.530 & 0.0 & 54.60 & 8.47 & 0.23 \\
\hline 14 & 7.5 & 99.5 & 417.4 & 1.301 & 0.0 & 54.60 & 22.79 & 2.42 \\
\hline 15 & 1.15 & 103.6 & 434.2 & 1.347 & 0.0 & 6.58 & 2.86 & 0.31 \\
\hline 16 & 6.023 & 159.0 & 671.1 & 1.932 & 0.0 & 67.48 & 45.30 & 7.82 \\
\hline 17 & 91.20 & 160.2 & 681.2 & 1.934 & 0.0 & 67.48 & 45.97 & 8.47 \\
\hline 18 & 21.81 & 217.0 & 929.0 & 2.488 & 0.0 & 7.40 & 6.88 & 1.58 \\
\hline 19 & $====$ & $====$ & $====$ & $====$ & $===$ & $====$ & 66.49 & 66.49 \\
\hline 20 & $===$ & $====$ & $====$ & $====$ & $===$ & $====$ & 65.16 & 65.16 \\
\hline 21 & $====$ & $====$ & $====$ & $====$ & $===$ & $====$ & 0.89 & 0.89 \\
\hline
\end{tabular}




\begin{tabular}{|l|l|l|l|l|l|l|c|c|}
\hline 22 & $====$ & $====$ & $====$ & $====$ & $===$ & $====$ & 64.27 & 64.27 \\
\hline 23 & === & ==== & ==== & ==== & $===$ & $====$ & 0.15 & 0.15 \\
\hline 24 & $====$ & $====$ & $====$ & $====$ & $===$ & $====$ & 0.06 & 0.06 \\
\hline 25 & $====$ & $====$ & $====$ & $====$ & $===$ & $====$ & 0.68 & 0.68 \\
\hline
\end{tabular}

Figures 3 and 4 show the detailed energy and exergy balance of the considered power plant at full operating load. There is a striking difference in the composition of the represented energy and exergy balances. Figure 3 shows that the condenser has the most energy losses in power plant. Figure 4 shows that the boiler has the most exergy losses in power plant. These figures illustrate the difference between energy and exergy analysis. It has been found that the exergy

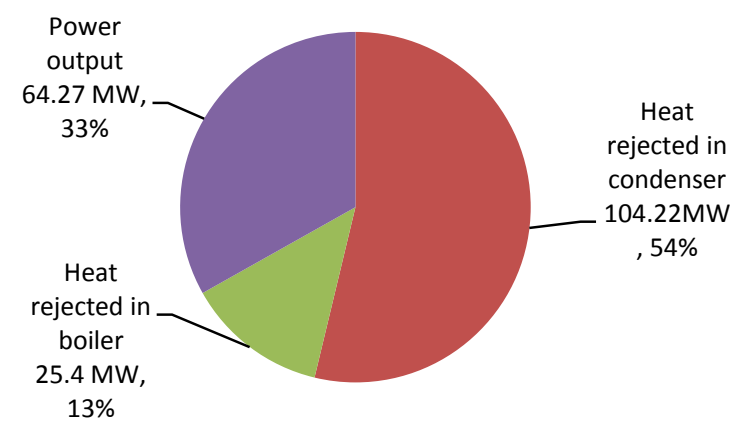

Figure 3: Energy balance of the power plant at full load. analysis has enabled the identification of the causes of process inefficiencies in detail when compared to the energy analysis.

Exergy destruction and exergy destruction ratio at different loads are summarized in Table 3 for all components present in the power plant. It was found that the exergy destruction and exergy destruction ratio of the boiler is dominant over all other irreversibilities in the cycle at all part loads.

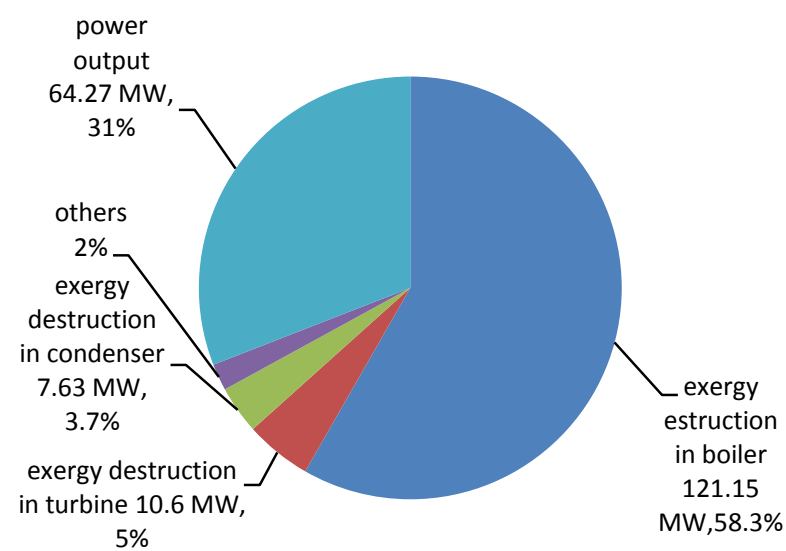

Figure 4: Exergy balance of the power plant at full load.

Table 3: Exergy destruction and exergy distraction ratio at different loads.

\begin{tabular}{|c|c|c|c|c|c|c|}
\hline Load & \multicolumn{2}{|c|}{$50 \%$} & \multicolumn{2}{c|}{$70 \%$} & \multicolumn{2}{c|}{$100 \%$} \\
\hline Component & $\begin{array}{c}\text { EXD } \\
(\mathrm{MW})\end{array}$ & $\begin{array}{c}\text { EXDR } \\
(\%)\end{array}$ & $\begin{array}{c}\text { EXD } \\
(\mathrm{MW})\end{array}$ & $\begin{array}{c}\text { EXDR } \\
(\%)\end{array}$ & $\begin{array}{c}\text { EXD } \\
(\mathrm{MW})\end{array}$ & $\begin{array}{c}\text { EXDR } \\
(\%)\end{array}$ \\
\hline Boiler & 61.03 & 58.72 & 85.10 & 58.5 & 121.15 & 58.28 \\
\hline Turbine & 4.86 & 4.67 & 7.12 & 4.89 & 10.56 & 5.1 \\
\hline Condenser & 3.1 & 3.0 & 4.7 & 3.22 & 7.63 & 3.67 \\
\hline LPH & 0.40 & 0.4 & 0.7 & 0.47 & 1.20 & 0.57 \\
\hline De-aerator & 0.31 & 0.30 & 0.48 & 0.33 & 0.80 & 0.38 \\
\hline HPH6 & 0.32 & 0.31 & 0.48 & 0.33 & 0.74 & 0.36 \\
\hline EG & 0.62 & 0.60 & 0.90 & 0.62 & 1.33 & 0.64 \\
\hline CWP & 0.0034 & 0.003 & 0.006 & 0.004 & 0.01 & 0.005 \\
\hline CEP & 0.0035 & 0.003 & 0.005 & 0.003 & 0.006 & 0.003 \\
\hline BFWP & 0.0076 & 0.007 & 0.016 & 0.011 & 0.033 & 0.002 \\
\hline Steam Valve & 3.1 & 3.0 & 2.32 & 1.6 & 0.144 & 0.07 \\
\hline $\begin{array}{c}\text { Total exergy } \\
\text { destruction }\end{array}$ & 73.7 & 71.0 & 101.80 & 70.0 & 143.60 & 69.1 \\
\hline Power output & 30.22 & 29.1 & 43.72 & 30.0 & 64.27 & 31.0 \\
\hline Total exergy & 103.9 & 100 & 145.5 & 100 & 207.87 & 100 \\
\hline
\end{tabular}


The variation of power output with load is shown in Fig. 5. The obtained variation is $34.05 \mathrm{MW}$ for the load variation of $50 \%$.

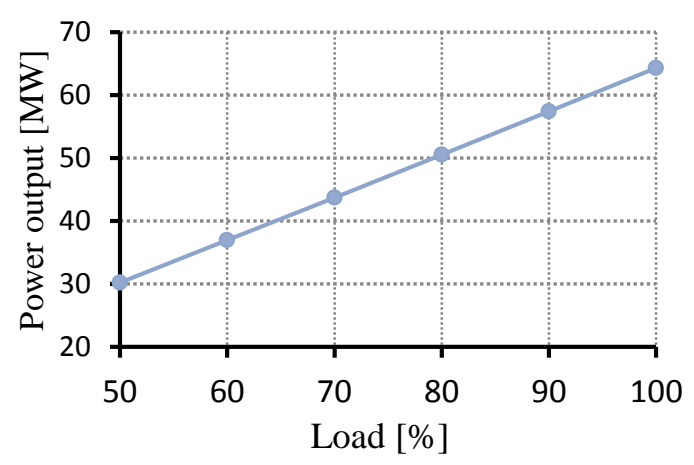

Figure 5: Variation of power output with load.

Figure 6 presents the variations of SFC and HR for steam the cycle with boiler-load. Since, the decrease in the boiler-load would reduce the power output and thermal efficiency, thus both the SFC and HR increase with the decrease in boiler-load. It is seen that the SFC and HR increase by 16 grams/kWh and 693 $\mathrm{kJ} / \mathrm{kWh}$, respectively with the decrease in load from $100 \%$ to $50 \%$.

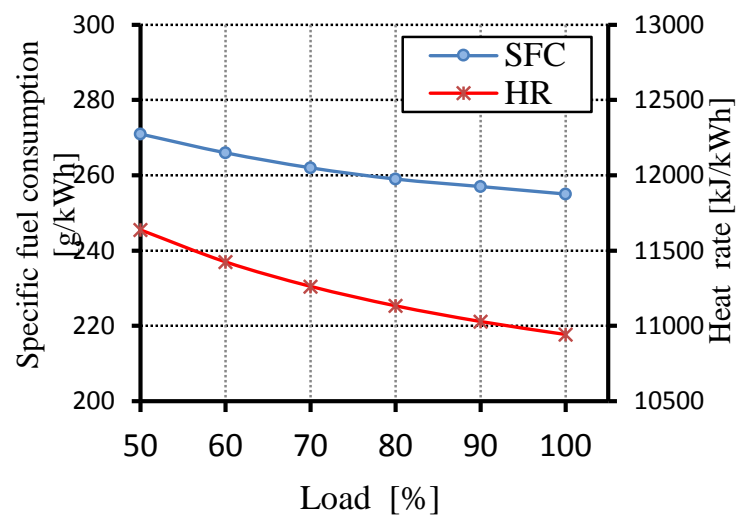

Figure 6: Variation of SFC and HR of the power plant with respect to load.

The variation of the overall energy and exergy efficiencies and total exergy destruction ratio is presented in Figure 7. It shows that, a decrease in overall energy and exergy efficiencies and an increase in total exergy destruction ratio with decrease in load. It is evident from this Figure that operation of the power plant below the designed capacity results in the significant increase of irreversibilities. The increase in total exergy destruction ratio is attributed to the increase in irreversibilities in the power plant components. At $50 \%$ load, the analysis shows a drop in overall energy and exergy efficiencies of $2.0 \%, 1.9 \%$ respectively, while the total exergy destruction ratio increases from $69.1 \%$ to $71.0 \%$. These results are in a good agreement with findings reported by Suresh et al. [9].

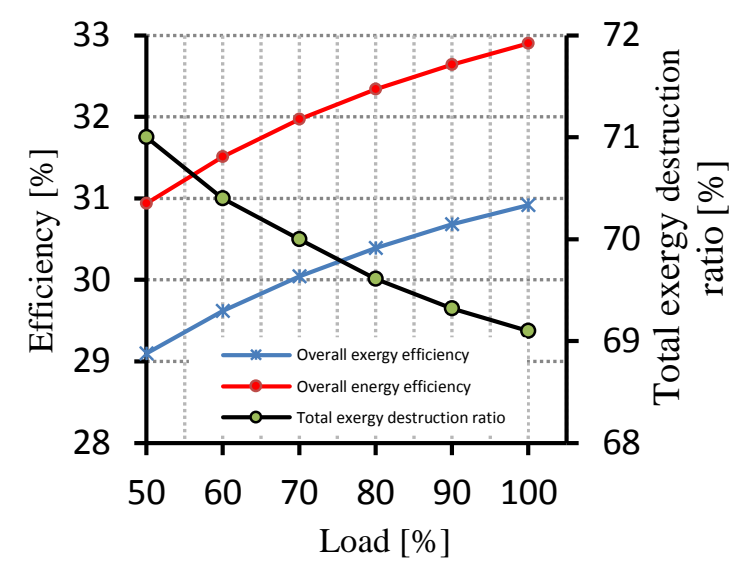

Figure 7: Variation of overall energy and exergy efficiencies and total exergy destruction ratio with load.

Figure 8 shows the variation of exergy destruction rates of the system components with load. From the Figure it is observed that, the exergy destruction decrease in all components is the result of the reduction of mass flow-rate of steam in the cycle at part loads. The results reveal a 60.2 MW, 5.7 MW, 4.53MW and 0.5 MW decrease in the boiler, turbine, condenser and other components respectively, for a $50 \%$ decrease in the plant load.

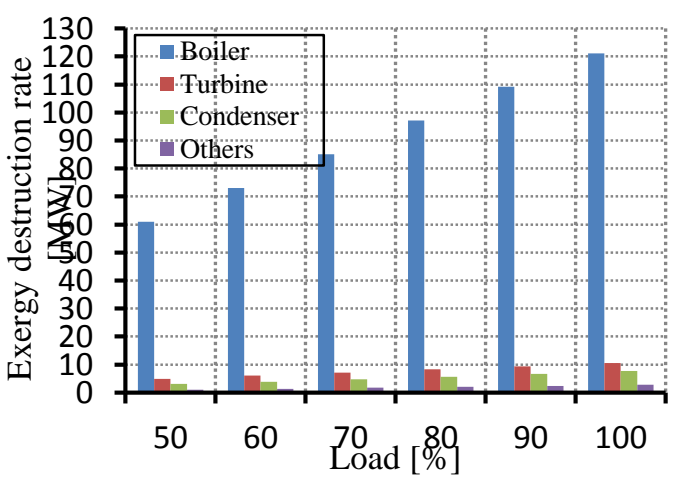

Figure 8: Variation of the exergy destruction rate in power plant components with boiler-load. 
The variation in the exergy flowrates of the turbine extraction points at the different loads is shown in Figure 9. It is seen that, the exergy flow-rates decrease with the reduction in boiler-load. The decrease in exergy flow-rates is due to the decreased mass flow rates of the steam through turbine stages.

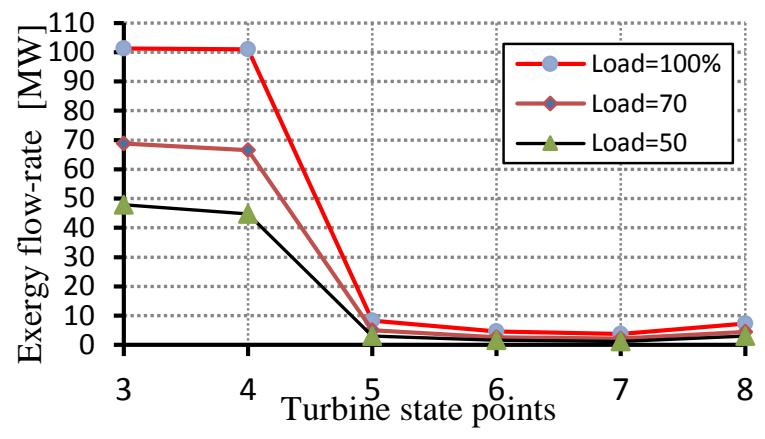

Figure 9: Variation of turbine extraction exergy flow-rates with respect to load.

\section{CONCLUSIONS}

In the present work, energy and exergy analysis has been carried out for an actual steam power plant at part load conditions. For each component in the power plant and for the overall power plant, the exergy destruction and exergy destruction ratio are computed in different loads ranging from $50 \%$ to $100 \%$ of the design load. Moreover, the overall energy and exergy efficiencies, heat rate and specific fuel consumption of the total cycle were obtained. The following are the main conclusions of the present work:

1- The energy losses are associated mainly with heat rejected in condenser and stack whereas exergy losses (useful energy losses) are dominated by the losses in steam generator unit and turbine at full and part loads.

2- The steam generator is the major source of irreversibilities in the power plant at full and part loads. This is due to higher fuel exergy and chemical reactions of fuel with air, and heat transfer inside the steam generator unit.
3- By reducing the load, the total exergy destruction ratio is increased and causes a decrease in the overall exergy efficiency. This point may imply that the power plant achieves minimum exergy destruction ratio and maximum exergy efficiency at its design rated load.

4- The energy and exergy efficiencies decrease by $2.0 \%$ and $1.9 \%$ respectively, at $50 \%$ load when compared with values at full load.

Finally, the results reveal that the energy and exergy efficiencies, exergy destruction, power output, heat rate and specific fuel consumption depend on the power plant operating load. The present study has enabled us to identify and quantify the sites having largest energy and exergy losses in a $65 \mathrm{MW}$ steam power plant operating at different loads.

\section{REFERENCES}

[1] Szargut J., Morris D. R., and Steward F. R., Exergy Analysis of Thermal, Chemical and metallurgical process, Hemisphere, New York, 1988.

[2] Moran M. J., and Sciubba E., Exergy Analysis Principle and Practice. ASME J. Eng. Gas Turbines Power, 116 (1994), 285-290.

[3] Gaggioli R. A. et al., Pinpointing the Real Inefficiencies in Power Plants and Energy Systems. Proc. Am. Power Conf., 37 (1975), USA.

[4] Dincer I., Al-Muslim H., Thermodynamic Analysis of Reheat cycle Steam Power Plant, Int. J. of Energy Research 25 (2001) 727-739.

[5] Regulagadda P. I., Dincer I., and Natere, G.F., Exergy Analysis of a Thermal Powe Plant with Measured Boiler and Turbine Losses, Appl. Thermo. Eng., 30 (2010) 970-976.

[6] Rana A. H., Mehta J. R., Energy and Exergy Analysis of fully Condensing Steam Turbine at Various steam Load Condition, Int. J.1 of ChemTech 
Research, 5 (2013) 957-963. Regulagadda Rana

[7] Fallah M. G. Effect of Ambient Temperature on the Thermodynamic Performance of a Combined Cycle. J. of Eng. Research, Triply University 2011; 13: 35-48.

[8] Aljundi I. H., Exergy and Exergy analysis of a Steam power Plant in Jordan, Applied thermal engineering 29 (2009) 324-328.

[9] Suresh M.V.J.J., Reddy K. S., and Kolar A.K., Energy and Exergy Based Thermodynamic Analysis of a 62.5 MWe Coal-Based Thermal Power Plant- A Case Study, International Conference on Energy and Environment, (2006) 1-6, Malaysia.

[10] Osueke C. O., Onokwai A.O., and Adeoye, A. O., Energy and Exergy Analysis of a 75 MW Steam Power Plant in Sapele (Nigeria), IJIRAE, Vol 2, (2015), 2349-2163.

[11] Rashad A., and El-maihy A., Energy and Exergy Analysis of a steam power Plant in Egypt, $13^{\text {th }}$ Int. Conference on ASAT-13-TH-02 (2009) 1-12.

[12] Derna Power Plant Working Documents, 1980, Turbine and Boiler Units, Brown Boveri, Vol. 4. General Electricity Company in Libya.

[13] Miller A., Determination of the Effeciency of a Turbine Stage Under variable Operating Conditions, Archiwum Budowy Maszyn, 1975, 1, 55-66 (in polish).

[14] Cengel , Y. A., 1997, Introduction to Thermodynamics and Heat Transfer, McGraw-Hill, New York.

[15] Kreith F., Black W. Z., Basic Heat Transfer, Harper \& Row, New York, 1980.

\section{ACKNOWLEDGMENT}

Great thanks to the staff of General Electricity Company in Libya for providing me with needed data which really gave real meaning to this work.

NOMENCLATURE

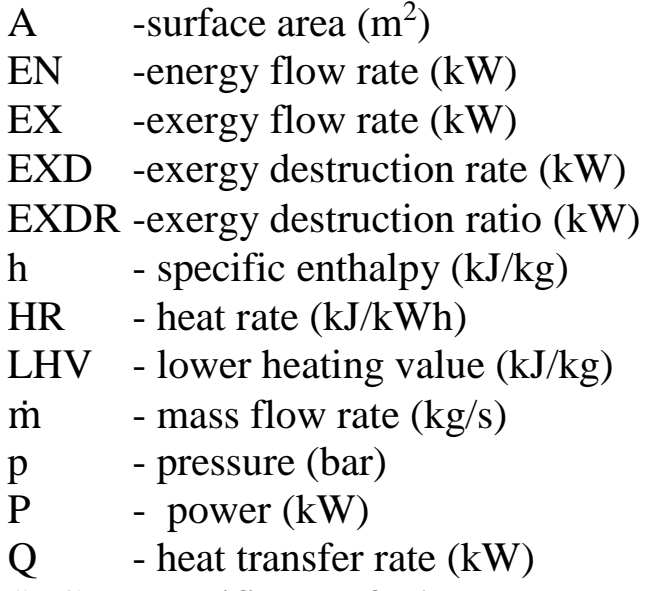

SFC -specific fuel consumption $(\mathrm{kg} / \mathrm{kWh})$

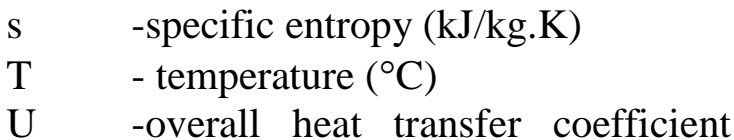
$\left(\mathrm{kW} / \mathrm{m}^{2} .{ }^{\circ} \mathrm{C}\right)$

$\mathrm{x} \quad$-dryness fraction of steam (-)

Abbreviations

\begin{tabular}{ll}
\hline BO & -boiler \\
BFWP & -boiler feedwater pump \\
CON & -condenser \\
CEP & -condenser extraction pump \\
CWP & -cooling water pump \\
DA & -deaerator \\
EG & -electrical generator \\
HPH & -high pressure heater \\
LPH & -low pressure heater \\
ST & -steam turbine \\
MBE & - model for solution of the balance \\
& Equations \\
MTP & - Model for evaluation \\
& thermodynamic properties \\
MPP & - Model for evaluation \\
& thermodynamic performance
\end{tabular}

\section{Greek Letters}

$\rho \quad$ - density $\left[\mathrm{kg} / \mathrm{m}^{3}\right]$

$\eta_{\mathrm{I}} \quad$ - energy efficiency [\%]

$\eta_{\mathrm{II}}$ - exergy efficiency [\%]

$\Delta p \quad$-pressure drop [bar]

$\triangle T L$-log-mean temperature different

[K]

\section{Subscripts}

\begin{tabular}{ll}
\hline is & -isentropic expansion \\
$\mathrm{r}$ & -reference or design condition \\
$\mathrm{p}$ & -pump \\
$\mathrm{W}$ & -water
\end{tabular}

1 to 25 - cycle state points in Fig. 1. 